\title{
SEED CHEMICAL COMPOSITION OF ENDEMIC PLANT FRAXINUS ORNUS SUBSP. CILICICA
}

\author{
TONGUÇ, F. \\ Isparta Applied Sciences University, Faculty of Forestry, Isparta, Turkey \\ (e-mail: fatihtonguc@isparta.edu.tr; phone: +90-246-211-3989; fax: +90-246-211-3948) \\ (Received 25 $5^{\text {th }}$ Feb 2019; accepted $15^{\text {th }}$ May 2019)
}

\begin{abstract}
The present study was conducted to determine the biochemical characteristics of Fraxinus ornus subsp. cilicica, seeds, an endemic tree species of Turkey. Seeds were collected from three provenances (Düziçi-Osmaniye, Andırın-Kahramanmaraş, Pozant1-Adana). Seed reserve composition (total soluble sugars, reducing sugars, carotenoids, xanthophylls, total soluble proteins, total tocopherol, total soluble phenolics, flavanoids and oil content) and seed fatty acids contents were examined. Total soluble sugars content and total tocopherol contents of seed among provenances did not differ significantly but other seed constituents were different among provenances. The highest amount of fatty acids present in F. ornus subsp. cilicica seeds were linoleic and oleic acids. The present study is the first report dealing with various aspects of seed composition and should provide valuable information for this endemic species.
\end{abstract}

Keywords: fatty acids, manna ash, taurus flowering ash, oil content, provenance

\section{Introduction}

Fraxinus ornus (L.) (Oleaceae), also known as Manna ash (Fraxigen, 2005), can be used for numerous purposes for example, afforestation/reforestation of deforested areas, urban landscape design, forest restoration and manna production. Manna refers to white or faded yellow sugary substance that dried exudates collected from diverse natural sources and used in several locations around the world as a traditional sweet, emergency food or traditional medicine to treat trivial diseases (Harrison, 1950). Manna production for many years was the source of mannitol used as nutritive sweetener (Debord et al., 1987; Wisselink et al., 2002). Mannas have been known from the earliest times, particularly in Asia Minor, where some mannas are still regularly used in the preparation of local sweets.

Fraxinus ornus subsp. cilicica (Lingelsh) Yalt., localy named as Taurus flowering ash, is an endemic tree species of Turkey. The species has ornamental value because of its flower, foliage and interesting crown form (Dirr and Heuser, 1987). This species is an insect-pollinated tree (Verdú et al., 2007), fruits are winged, elongated and single seeded samaras borne in clusters (Bonner, 2008). It is distributed on southern parts of Turkey, mostly on Taurus and Amanos mountains in the East. Taurus flowering ash could reach 8-10 m height and sometimes reach up to $20 \mathrm{~m}$ height (Yaltirik, 1978; Browicz, 1982; Yilmaz and Tonguç, 2009). Taurus flowering ash mostly found in karstic areas on sunny southern slopes and grows from $350 \mathrm{~m}$ to $1500 \mathrm{~m}$ above sea level. Throughout its natural distribution areas, it is scattered generally as individual trees and rarely as clusters and groups. F. ornus subsp. cilicica wood is used to make shovel handles and therefore scattered populations of this species are under the threat of illegal harvest (Yilmaz and Tonguç, 2013a). However, there are no special conservation programs for the tree species in Turkey. In the last decades, there is an increasing awareness in using native local trees for reforestation and urban planting studies (Grey and Deneke, 1992; Ürgenç, 1998). 
Forestry activities are long-term investments, therefore use of high quality seeds are critical to have successful seedling establishment. Factors in relation to the provenance and genetic diversity among the populations together with variety within origins should be taken into consideration because field performance of the seeds obtained from different origins of the same species might be varied greatly (Evans, 1982; Duryea, 1985). Though high quality seeds have fundamental importance for success in plantation forestry, chemical properties are yet more important. The term of high quality seeds for reforestation and urban planting studies refers to not only provenance but more importantly chemical composition of the seeds (Ayaz et al., 2011). While many studies deal with seed size, seed dispersal and seed size and seedling establishment, research on seed reserve contents of forest trees has been started studying recently (Brancalion et al., 2008; Soriano et al., 2011; Ataíde et al., 2013).

Although some studies on the seed morphology and physiology (Yilmaz and Tonguç, 2009; Yilmaz and Tonguç, 2013b) and seed fatty acid and mineral content (Ayaz et al., 2011) of endemic Fraxinus ornus subsp. cilicica species were carried out, there is no detailed studies on the seed chemical composition. The purpose of the present study was to obtain information regarding to the chemical composition of F. ornus subsp. cilicica seeds collected from three different provenances.

\section{Material and methods}

\section{Seed collection}

Fraxinus ornus subsp. cilicica seeds were collected from three provenances; DüziçiOsmaniye, Andırın-Kahramanmaraş and Pozant1-Adana. The seeds were collected in October 2016 at least from 10 individual trees and were packed and transported to the laboratory. Seeds were air dried and 400 seeds were taken and seed wings were removed before the analysis. Taurus ash seed morphologies were analyzed in detail previously among the provenances and therefore they were not included in the present study (Yilmaz and Tonguç, 2009, 2013a). Seed provenances and their locality properties were given in Table 1 and Figure 1.

Table 1. Seed provenances and their localities used in the study

\begin{tabular}{c|c|c|c|c|c}
\hline Provenances & Latitude & Longitude & Altitude (m) & $\begin{array}{c}\text { Mean annual } \\
\text { rainfall (mm) }\end{array}$ & $\begin{array}{c}\text { Mean annual } \\
\text { temperature }\left({ }^{\circ} \mathbf{C}\right)\end{array}$ \\
\hline Adana (Pozantı) & $37^{\circ} 22^{\prime}$ & $34^{\circ} 53^{\prime}$ & 1150 & 916.9 & 11.1 \\
\hline Kahramanmaraş (Andırın) & $37^{\circ} 32^{\prime}$ & $36^{\circ} 18^{\prime}$ & 950 & 1477.2 & 14.2 \\
\hline Osmaniye (Düziçi) & $37^{\circ} 16^{\prime}$ & $36^{\circ} 30^{\prime}$ & 1400 & 1362.9 & 11.2 \\
\hline
\end{tabular}

\section{Biochemical analyses}

All chemicals were purchased either from Merck-Millipore (Darmstadt, Germany) or Sigma-Aldrich Chemical Co. (St Louis, USA). Spectrophotometric measurements were made on a T80 spectrophotometer (PG Instruments, UK). Total soluble and reducing sugars were extracted as described by Tonguç et al. (2012). The total soluble sugars content was determined by the phenol sulfuric acid assay (DuBois et al., 1956) and the reducing sugars content was determined by Somogyi method (Somogyi, 1952). Glucose was used as standard and the results were expressed as $\mathrm{mg} / \mathrm{g}$ dry weight. Total 
carotenoids and xanthophylls contents were determined according to Association of Official Analytical Chemists (AOAC) (AOAC, 1984). $10 \mathrm{ml}$ of acetone-hexane (4:6) solvent was added to $1.0 \mathrm{~g}$ pulverized seed samples and the mixture was shaken at 15 minutes and the upper phase was washed twice with $20 \% \mathrm{NaCl}$ solution. Two phases were separated, and the aliquots were taken from the upper phase and read on a spectrophotometer at 436 and $474 \mathrm{~nm}$ wavelengths. The protein extraction was performed according to the method of Larson and Beevers (1965) and the total soluble protein content was determined following Hartree method (Hartree, 1972). Bovine serum albumin (BSA) was used as standard. Total tocopherol content was determined according to modified Emmerie-Engel method (Baker et al., 1980). Standard curve was prepared using $\alpha$-tocopherol. Total soluble phenolics and flavonoid contents of the seeds were determined following procedures of Sakanaka et al. (2005). Standart curve was prepared using (+)-catechin solution and the results were expressed as $\mathrm{mg} / \mathrm{g}$ dry weight.

The oil content and fatty acid composition of the seeds were determined using Nuclear magnetic resonance (NMR, Bruker mq-one, USA) and Gas chromatography (GC, Perkin Elmer Auto System XL, USA), respectively. The oil samples (50-100 mg) were extracted and converted to its fatty acid methyl esters (FAME) by the method of Maquard (1987). GC-MS analysis was performed as described by Tonguç and Erbaş (2012). Total free fatty acids content of seeds (\%) was determined as oleic acid equivalents.

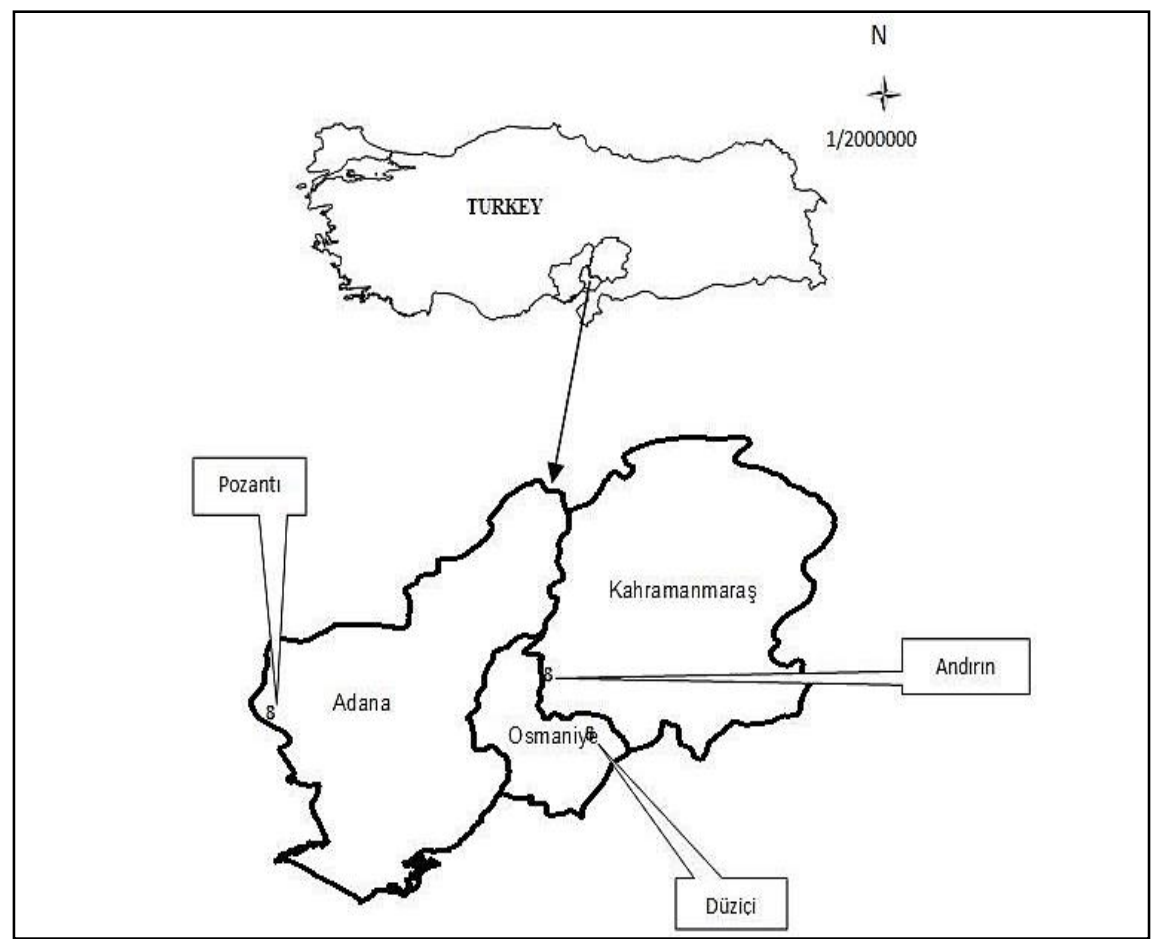

Figure 1. Location map of seed collection sites

\section{Statistical analysis}

Chemical compositions of provenances were measured 3 times independently and results were analyzed with the analysis of variance (ANOVA). To determine differences between the means, Duncan's Multiple Range test was performed. 


\section{Results and Discussion}

Total of nine parameters related to seed reserves as well as fatty acids compositions were measured to determine chemical composition of $F$. ornus subsp. cilicica seeds from 3 provenances. The highest reducing sugars content was found from seeds collected from Adana $(146.32 \mathrm{mg} / \mathrm{g})$ followed by Kahramanmaraş $(141.29 \mathrm{mg} / \mathrm{g})$ and Osmaniye $(138.52 \mathrm{mg} / \mathrm{g})$, however reducing sugars content of the seeds collected from Kahramanmaraş and Osmaniye did no differ significantly. On the other hand, total soluble sugars contents was not statistically significant among the provenances (Table 2).

The highest total carotenes $(0.894 \mathrm{mg} / \mathrm{g})$ and xanthophylls $(0.586 \mathrm{mg} / \mathrm{g})$ contents were obtained from seeds collected in Osmaniye. Unlike reducing sugars content, F. ornus subsp. cilicica seeds from Osmaniye provenance had higher carotene $(0.894 \mathrm{mg} / \mathrm{g})$ and xanthophylls $(0.586 \mathrm{mg} / \mathrm{g})$ contents than $F$. ornus subsp. cilicica seeds collected from Adana and Kahramanmaraş.

Table 2. Chemical composition of F. ornus subsp. cilicica seeds from different origins

\begin{tabular}{c|c|c|c|c|c|c|c|c|c}
\hline Provenance & $\begin{array}{c}\text { Reducing } \\
\text { sugars } \\
(\mathbf{m g} / \mathbf{g})\end{array}$ & $\begin{array}{c}\text { Total } \\
\text { soluble } \\
\mathbf{s u g a r s} \\
(\mathbf{m g} / \mathbf{g})\end{array}$ & $\begin{array}{c}\text { Carotenes } \\
(\mathbf{m g} / \mathbf{g})\end{array}$ & $\begin{array}{c}\text { Xanthophyll } \\
(\mathbf{m g} / \mathbf{g})\end{array}$ & $\begin{array}{c}\text { Total } \\
\text { Soluble } \\
\mathbf{p r o t e i n s} \\
(\mathbf{m g} / \mathbf{m l})\end{array}$ & $\begin{array}{c}\text { Total } \\
\text { tocopherol } \\
(\mathbf{m g} / \mathbf{g})\end{array}$ & $\begin{array}{c}\text { Total } \\
\text { soluble } \\
\mathbf{p h e n o l i c s} \\
(\mathbf{m g} / \mathbf{g})\end{array}$ & $\begin{array}{c}\text { Flavonoids } \\
(\mathbf{m g} / \mathbf{g})\end{array}$ & $\begin{array}{c}\text { Total oil } \\
\text { content } \\
(\boldsymbol{\%})\end{array}$ \\
\hline Adana & $146.32 \mathrm{a}^{*}$ & 200.24 & $0.776 \mathrm{~b}^{*}$ & $0.517 \mathrm{c}^{* *}$ & $10.06 \mathrm{~b}^{*}$ & 76.16 & $5.95 \mathrm{a}^{*}$ & $2.22 \mathrm{a}^{*}$ & $23.83 \mathrm{c}^{* *}$ \\
Kahramanmaraş & $141.29 \mathrm{ab}$ & 199.96 & $0.763 \mathrm{~b}$ & $0.556 \mathrm{~b}$ & $9.10 \mathrm{~b}$ & 76.94 & $5.35 \mathrm{~b}$ & $2.18 \mathrm{a}$ & $28.42 \mathrm{a}$ \\
Osmaniye & $138.52 \mathrm{~b}$ & 199.52 & $0.894 \mathrm{a}$ & $0.586 \mathrm{a}$ & $11.47 \mathrm{a}$ & 76.48 & $4.70 \mathrm{c}$ & $1.89 \mathrm{~b}$ & $25.18 \mathrm{~b}$ \\
\hline
\end{tabular}

The values on the same row followed by the same letter are not significantly different at $\mathrm{p}<0.05$

Total soluble protein content was also differed significantly between the seed sources. Protein content was not significantly differed between Adana and Kahramanmaraş (Table 2). The highest protein content among the seeds was observed in Osmaniye provenance $(11.47 \mathrm{mg} / \mathrm{ml})$ and the lowest protein content was found in seeds from Kahramanmaraş $(9.10 \mathrm{mg} / \mathrm{ml})$.

Total tocopherol content of $F$. ornus subsp. cilicica seeds were close to each other and varied between 76.16-76.94 mg/g. While seeds from Adana had lower tocopherol content than the seeds from Kahramanmaraş and Osmaniye provenances, the difference was not statistically significant.

Total soluble phenolics content was significantly differed among the provenances and changed between $4.70-5.95 \mathrm{mg} / \mathrm{g}$, and the highest soluble phenolics content was observed from the seeds collected from Adana provenance. Total flavanoid content ranged between 1.89-2.24 mg/g among the seed sources and was different between Osmaniye and Adana-Kahramanmaraş provenances.

Total oil content was also measured and statistically different variations were found among the seeds collected from Adana, Kahramanmaraş and Osmaniye provenances. Seeds from Kahramanmaraş had the highest oil content $(28.42 \%)$ while seeds from Adana (23.83\%) and Osmaniye (25.18\%) had lower oil contents.

Fatty acid compositions of $F$. ornus subsp. cilicica seeds from different seed provenances were also examined. GC/MS analysis revealed 3 major fatty acids (C16:0 palmitic acid, C18:1 oleic acid, C18:2 linoleic acid) and 5 minor fatty acids (C16:1 hexenoicacid, C17:0 heptadecanoic acid, C18:0 stearic acid, C18:3 linolenic acid). Detected fatty acids accounted more than $97 \%$ of total fatty acids found in F. ornus 
subsp. cilicica seeds. Majority of the fatty acids were unsaturated fatty acids and linoleic and oleic acids constituted the majority of the unsaturated fatty acids. Palmitic acid had the highest amount among the saturated fatty acids (Table 3).

Seeds contain carbohydrates, proteins and lipids as reserve molecules and they are usually accumulated as insoluble large macromolecules (Vidigal et al., 2016). These macromolecules are the fundamental constituent of seed biomass and are the source of energy playing important roles for the seedling during germination, early development and survival (Soriano et al., 2011; Wahid and Bounoua, 2013; Zhao et al., 2018). During the germination enzymatic pathways are activated upon imbibition to convert these molecules into smaller soluble units for energy production and synthesis of new molecules (Bewley et al., 2013). Other molecules, such as vitamins, carotenoids and xanthophylls, are also present in seeds in varying amounts. Presence of these molecules protects seeds from enzymatic and non-enzymatic lipid peroxidation during the storage and germination (Priestley, 1986). Information on chemical composition of seeds belong to wild species is scarce therefore some chemical parameters were determined for $F$. ornus subsp. cilicica seeds in the present study.

Table 3. Fatty acid contents (\%) of F. ornus subsp. cilicica seeds

\begin{tabular}{c|c|c|c|c|c}
\hline \multirow{2}{*}{ Fatty Acid } & \multicolumn{2}{c}{ RT* $^{*}$} & \multicolumn{3}{c}{ Seed Provenance } \\
\cline { 5 - 6 } & & 24.564 & 11.69 & 8.88 & 11.36 \\
C16:0 & Palmitic acid & 25.234 & 0.31 & 0.75 & 1.24 \\
C16:1C7 & 7-hexenoic acid & 25.23 & 0.24 & 1.55 \\
C16:1C9 & 9-hexenoic acid & 27.013 & 0.16 & 0.25 & 0.95 \\
C17:0 & Heptadecanoic acid & 29.408 & 0.32 & 1.99 & 3.05 \\
C18:0 & Steraic acid & 32.780 & 2.65 & 17.50 & 19.12 \\
C18:1 & Oleic acid & 33.408 & 24.73 & 66.67 & 56.33 \\
C18:2 & Linoleic acid & 34.916 & 57.56 & 0.95 & 0.70 \\
C18:3 & Linolenic acid & 37.193 & 0.60 & & \\
\hline
\end{tabular}

*Retention time

It has been reported that type and amount of seed reserves have influence on germination rate, germination percentage or both (Zhao et al., 2018). Different reserves have different influence on germination for example protein content was positively correlated with germination percentage in different tree speceies (Brancalion et al., 2006; Soriano et al., 2011; Wahid and Bounoua, 2013), yet total soluble sugars content was not have influence on germination percentage in Pinus pinaster (Wahid and Bounoua, 2013) and did not significantly different among the seeds of the different populations. Oilseed species such as sunflower and safflower seeds showed significant reduction of protein and oil reserves during the germination and early seedling growth, but total soluble sugars and reducing sugars did not decreased significantly (Tonguç et al., 2012; Erbaş et al., 2016). Seed germination parameters have been studied previously (Yilmaz and Tonguç, 2013a,b) but we did not investigate type of the reserves used during the germination and early seedling growth. Different species use different reserves for germination and $F$. ornus subsp. cilicica seeds are rich in sugars, proteins and lipids and their role in germination should be investigated further to ascertain their role during germination and seedling growth.

Environmental factors and seed provenances may influence seed morphology and reserve composition. In a previous stduy, seed morphologies of $F$. ornus subsp. cilicica trees colleceted from 8 provenances were described (Yilmaz and Tonguç, 2009). While 
there were differences among the seed morphologies depending on provenances, only the mean temperature had influence on samara width among the studied parameters. In the present study, mean temperature of Kahramanmaraş was different to have an influence on seed morphology. Total soluble sugars and tocopherol amounts did not differ significantly between provenances, but other reserves of the seeds showed significant differences among the provenances. (Table 2). Effects of precipitation on seed lipid, protein and sugar contents on 19 tree species were reported. Lower rainfall increased seed protein content of 12 species while it reduced sugar content of seeds in 2 species. Lipid content of 5 species decreased and one species showed increased lipid content out of 19 tree species in Mexico (Soriano et al., 2011). Phenolics and flavonoids in the seeds have major roles for protecting plant species against insect feeding, herbivory and abiotic stresses such as drought, temperature flactuations, lipid peroxidation (Mierziak et al., 2014). Caratenoids and xhanthophylls are present in photosynthetic tissues and in seeds and protect plants from oxidative damage. Caratenoids in plant seeds also involved in abscisic acid production and seed dormancy (Howit and Pogson, 2006). Tocopherols are also present in seeds and their major role is the prevention of lipid peroxidation during seed storage and germination (Sattler et al., 2004). In the present study, amount of caratenoids and xanthophylls, and total phenolics and flavanoids was different among the seeds from the provenances, suggesting different mechanisms may have involved in the accumulation of these compounds. We have studied effects of storage temperature and seed moisture content of $F$. ornus subsp. cilicica seeds collected from 5 provenances (Yilmaz et al., 2014) but their effects on seed storability have not been investigated. The present study will be helpful to investigate seed storage compounds and seed storability of $F$. ornus subsp. cilicica seeds.

The present study is a preliminary study to determine some seed reservers of F. ornus subsp. cilicica seeds and was conducted one year therefore it was not possible to identify. Influence of environmental factors on seed reserve composition at present. Multi year studies must be conducted to deliminate effects of environmental factors on seed reserve composition.

Seed fatty acid composition have also been investigated. Majority of fatty acids were mono and poly unsaturated fatty acids in $F$. ornus subsp. cilicica seeds. GC/MS analysis revealed $97 \%$ of fatty acids present in seeds therefore there are other undetected fatty acids and their amounts and types should be investigated further. Lajara et al. (1990) and Bozan and Kaplan (2007) stated that fatty acid profiles are affected by temperature, plant species, genotype and environmental conditions. Differences in fatty acid compositions might be due to lower altitude of seed source and therefore the warmer climate of Kahramanmaraş compared to other provenances (Tables 1, 3). Similar results were reported by Ayaz et al. (2011) that provenances in the cooler temperatures were tended to deposit higher levels of oleic acid for Fagus orientalis seeds.

\section{Conclusion}

The present study was conducted to quantify different seed reserves and chemical constituents in F. ornus subsp. cilicica seeds. Seed reserves such as seed oil content and 8 other seed reserves involving in different features of seed life and seed fatty acid contents have been investigated. Seven compounds present in seeds were differently accumulated in seeds dependeing on seed source. Total soluble sugars and total 
tocopherol contents among the provenances were not different. Eight different fatty acids have been detected in $F$. ornus subsp. cilicica seeds and majority of fatty acids were unsaturated fatty acids. Previous studies revealed that seed reserve accumulation depends on many factors such as environment and maternal plants, and seed provenances differ in their germination capabilities. Further studies would be necessary to conduct to investigate type of reserves accumulated in different seasons and used during the seed germination and their effects on germination capability among different seed provenaces of $F$. ornus subsp. cilicica seeds.

\section{REFERENCES}

[1] AOAC (1984): Official Methods of Analysis, Association of Official Analytical Chemists. $-14^{\text {th }}$ ed. Washington DC.

[2] Ataíde, G. D. M., Borges, E. E. D. L., Guimarães, V. M., Flores, A. V., Bicalho, E. M. (2013): Alterations in seed reserves of Dalbergia nigra ((Vell.) Fr All. Ex Benth.) during hydration. - Journal of Seed Science 35: 56-63.

[3] Ayaz, F. A., Glew, R. H., Turna, I., Güney, D., Chuang, L. T., Chang, Y. C., Andrews, R., Power, L., Presley, J., Torun, H., Şahin, N. (2011): Fagus orientalis (Oriental beechnut) seeds are a good source of essential fatty acids, amino acids and minerals. Food 5: 48-51.

[4] Baker, H., Frank, O., DeAngelis, B., Feingold, S. (1980): Plasma tocopherol in man at various times after ingesting free or acetylated tocopherol. - Nutrition Reports International 21(4): 531-536.

[5] Bewley, J. D., Bradford, K., Hilhorst, H., Nonogaki, H. (2013): Environmental regulation of dormancy and germination. - In: Seeds. Springer, New York, NY.

[6] Bonner, F. T. (2008): Storage of Seed. - In: Bonner, F. T., Karrfalt, R. P. (eds.) The Woody Plant Seed Manual. Agriculture Handbook 727, USDA Forest Service.

[7] Bozan, B., Karakaplan, U. (2007): Antioxidants from laurel (Laurus nobilis L.) berries: influence of extraction procedure on yield and antioxidant activity of extracts. Alimentaria 36(3): 321-328.

[8] Brancalion, P. H., Tay, D., Rodrigues, R. R., Novembre, A. D., Cunha, L. D. (2006): Seed imbibition of five Brazilian native tree seeds. - Acta Horticulturae 771: 77-81.

[9] Browicz, K. (1982): Chorology of Trees and Shrubs in South-West Asia and Adjacent Regions. - Polish Scientific Publishers, Poznan.

[10] Debord, B., Lefebvre, A. M., Guyot-Hermann, J., Bouche, H. R., Cuyot, J. C. (1987): Study of different forms of mannitol: Comparative behaviour under compression. - Drug Development and Industrial Pharmacy 13(9-11): 1533-1546.

[11] Dirr, M. A., Heuser, C. W. (1987): The reference Manual of Woody Plant Propagation. Varsity Press, Athens, GA.

[12] DuBois, M., Gilles, K. A., Hamilton, J. K. (1956): Colorimetric method for determination of sugars and related substances. - Analytical Chemistry 28: 350-356.

[13] Duryea, M. L. (1985): Evaluating Seedling Quality: Principles, Procedures and Predictive Abilities of Major Tests. - Forest Research Labarotory, Oregon State University, Corvallis.

[14] Erbaş, S., Tonguç, M., Karakurt, Y., Şanli, A. (2016): Mobilization of seed reserves during germination and early seedling growth of two sunflower cultivars. - Journal of Applied Botany and Food Quality 89: 217-222.

[15] Evans, J. C. (1982): Plantation Forestry in the Tropics. - Claridon Press, Oxford, UK.

[16] Fraxigen (2005): Ash Species in Europe: Biological Characteristics and Practical Guidelines for Sustainable Use. - UK: Oxford Forestry Institute, University of Oxford, Oxford. 
[17] Grey, G. W., Deneke, F. J. (1992): Urban Forestry. - Krieger Publishing, Florida, USA.

[18] Harris, H. C., McWilliam, J. R., Mason, W. K. (1978): Influence of temperature on oil content and composition of sunflower seed. - Australian Journal of Agricultural Research 29: 1203-1212.

[19] Harrison, S. G. (1950): Manna and its sources. - Kew Bulletin 5(3): 407-417.

[20] Hartree, E. F. (1972): Determination of protein: A modification of the Lowry method that gives a linear photometric response. - Analytical Biochemistry 48(2): 422-427.

[21] Howitt, C. A., Pogson, B. J. (2006): Carotenoid accumulation and function in seeds and non-green tissues. - Plant, Cell \& Environment 29(3): 435-445.

[22] Lajara, J. R., Diaz, U., Quidiello, R. D. (1990): Definite influence of location and climatic conditions on the fatty acid composition of sunflower seed oil. - Journal of the American Oil Chemists' Society 67(10): 618-623.

[23] Larson, L. A., Beevers, H. (1965): Amino acid metabolism in young pea seedlings. Plant Physiology 40: 424-432.

[24] Maquard, R. (1987): Qualitätsanalytik im Dienste der Ölpflanzenzüchtung. - Fat Science Technology 89: 95-99.

[25] Mierziak, J., Kostyn, K., Kulma, A. (2014): Flavonoids as important molecules of plant interactions with the environment. - Molecules 19(10): 16240-16265.

[26] Priestley, D. A. (1986): Seed Aging: Implications for Seed Storage and Persistence in the Soil. - Ithaca, NY.

[27] Sakanaka, S., Tachibana, Y., Okada, Y. (2005): Preparation and antioxidant properties of extracts of japanese persimmon leaf tea (kakinoha-cha). - Food Chemistry 89(4): 569575.

[28] Sattler, S. E., Gilliland, L. U., Magallanes-Lundback, M., Pollard, M., DellaPenna, D. (2004): Vitamin $\mathrm{E}$ is essential for seed longevity and for preventing lipid peroxidation during germination. - The Plant Cell 16(6): 1419-1432.

[29] Somogyi, M. (1952): Notes on sugar determination. - Journal of Biological Chemistry 195: 19-23.

[30] Soriano, D., Orozcosegovia, A., Márquezguzmán, J., Kitajima, K., Buen, A. G., Huante, P. (2011): Seed reserve composition in 19 tree species of a tropical deciduous forest in Mexico and its relationship to seed germination and seedling growth. - Annals of Botany 107: 939-951.

[31] Tonguç, M., Erbaş, S. (2012): Evaluation of fatty acid compositions and some seed characters of common wild plant species of Turkey. - Turkish Journal of Agriculture and Forestry 36: 673-679.

[32] Tonguç, M., Elkoyunu, R., Erbaş, S., Karakurt, Y. (2012): Changes in seed reserve composition during germination and initial seedling development of safflower (Carthamus tinctorius L.). - Turkish Journal Biology 36: 107-112.

[33] Ürgenç, S. (1998): Ağaçlandırma Tekniği. - İstanbul Üniversitesi, Orman Fakültesi Yayinlari, No: 3994/441, Istanbul.

[34] Verdú, M., Spanos, K., Čaňová, I., Slobodník, B., Paule, L. (2007): Similar gender dimorphism in the costs of reproduction across the geographic range of Fraxinus ornus. Annals of Botany 99(1): 183-191.

[35] Vidigal, D. S., Marques, A. C., Willems, L. A., Méndez-Vigo, B., Hilhorst, H. W., Bentsink, L., Picó, F. X., Alonso-Blanco, C. (2016): Altitudinal and climatic associations of seed dormancy and flowering traits evidence adaptation of annual life cycle timing in Arabidopsis thaliana. - Plant, Cell and Environment 39(8): 1737-1748.

[36] Wahid, N., Bounoua, L. (2013): The relationship between seed weight, germination and biochemical reserves of maritime pine (Pinus pinaster Ait.) in Morocco. - New Forests 44: 385-397.

[37] Wisselink, H. W., Weusthuis, R. A., Eggink, G., Hugenholtz, J., Grobben, G. J. (2002): Mannitol production by lactic acid bacteria: a review. - International Dairy Journal 12(23): $151-161$. 
[38] Yaltirik, F. (1978): Fraxinus L. - In: Davis, P. H. (ed.) Flora of Turkey and the East Aegean Islands. Edinburgh University Press, Vol. 6, Edinburgh.

[39] Yilmaz, M., Tonguç, F. (2009): Fruit and seed size variability of Fraxinus ornus subsp. cilicica. - International Journal of Natural and Engineering Sciences 3(3): 122-125.

[40] Yilmaz, M., Tonguç, F. (2013a): Effects of temperature on the germination of Fraxinus ornus subsp. cilicica seeds. - Dendrobiology 69: 111-115.

[41] Yilmaz, M., Tonguç, F. (2013b): Dormancy level and dormancy-breaking pretreatments in seeds of Fraxinus ornus subsp. cilicica, an endemic to Turkey. - Propagation of Ornamental Plants 13(1): 40-45.

[42] Y1lmaz, M., Tonguç, F., Ok, T. (2014): Storage effects of Fraxinus ornus subsp. cilicica seeds on seed viability and germination, an endemic tree in Turkey. - Süleyman Demirel Üniversitesi Orman Fakültesi Dergisi Seri A 15(1): 15-20.

[43] Zhao, M., Zhang, H., Yan, H., Qiu, L., Baskin, C. C. (2018): Mobilization and role of starch, protein, and fat reserves during seed germination of six wild grassland species. Frontiers in Plant Science 9(234): 1-11. 